\section{The No-Conscription Fellowship}

\author{
by $\mathcal{F}$ o Vellacott
}

Thomas C. Kennedy. The Hound of Conscience: A History of the NoConscription Fellowship, 1914-1919. Fayetteville, Ark.: University of Arkansas Press, 198I. Pp. xii, 322; 8 photographs. Us $\$ 20.00$.

PROFESSOR KENNEDY HAS written an important book. The story of the No-Conscription Fellowship during the First World War has long deserved a full scholarly treatment, and here we have it at last.

Kennedy's research is immensely impressive; he has used every known significant collection of papers, public and private, bearing on his subject, and has found a great deal that has not previously been used. In particular, his use of material recently brought to light at Friends' House Library in London (Euston Road) enables him to give a balanced and insightful view of the two main components in the leadership of the Fellowship, and to show the roots and growth of the conflicts which inevitably arose within the organization.

Much common ground existed between the young men who came into the NCF from an idealistic socialism and those who came in from Quakerism, via the Friends' Service Committee, and in many cases also via a prewar society of Quaker socialists; but, obviously, the seeds of division were also there. Idealists, even those committed to pacifism, are not necessarily among the most tolerant of mortals and it is not surprising that the Fellowship barely outlasted the war. Interestingly, two very different older men played an important part in bridging the gap when factions threatened to reduce the NCF to impotence. One was Bertrand Russell, whose sympathies were primarily with the socialist viewpoint, but who was respected by all and was sometimes able to bring both groups back from divisive issues to a consideration of their common goals. The other was Edward Grubb, the NCF's Quaker treasurer, who brought a knowledge of Quaker history and an experience of the Quaker spirit in practice which (I believe) exceeded that of the younger Friends; he was to remain as a Quaker presence in the National Committee after the intransigent young Friends had resigned.

The Chairman of the NCF throughout its history was the young socialist, Clifford Allen-Chairman in practice until his imprisonment, and rather more than merely nominally even during it, when Fenner Brockway, Bertrand Russell and Alfred Salter served in succession as Acting Chairmen. Allen's role is ambivalent; he chaired both the Na- tional Committee and the large conventions with such consummate skill and charisma that all remembered him as an impressive force for unity, and yet there were times when his tendency to a certain personal tunnel vision threatened further to divide the membership, as they wrestled with problems of alternative service, political action, and cooperation in prison.

Well told and well documented as Kennedy's story is, there are some points on which I take issue with his interpretation or emphasis. For myself, while I see value in outlining the prewar history of the conscription issue in Britain in order to put the wartime struggle in context, I would have preferred to have seen this condensed in favour of a more precise description of the process through which conscripted objectors went when they failed to get exemption, or were granted a form of exemption not acceptable to them. Kennedy's evaluation of the Tribunals and of the criticisms to which they were subject is thorough and fair, but the direct practical result of their work is not spelled out. Those who failed to get any exemption ended up in regular army units. Those who received exemption from combatant service were placed by the Army in the Non-Combatant Corps; for a large number of objectors this was a satisfactory solution (these were mostly religious objectors and were not members of the NCF). Most NCF members in the NCC refused to obey orders there just as did those who were denied any exemption and were sent to regular units.

I have gone into this much detail because I want to deal more fully with a central incident on which it bears-the case of the conscientious objectors who were taken to France and later sentenced to be shot, the sentence being commuted, after a pause, to ten years' penal servitude. This is part of the whole controversial matter of whether the dealings of the Army with the cos is a story of persecution or of administrative difficulty. Kennedy rightly decries J. W. Graham's tendency to exaggerate (Conscription and Conscience, I92I) and David Boulton's sensationalism (Objection Overruled, 1967) in dealing with all cases of injustice or ill treatment of cos. In reaction, perhaps, Kennedy has cut his own references to brutality down to so small a measure that the casual reader may almost miss them altogether; and yet they were important, if only as providing some test of the sincerity of men who knew what they might face.

As for the cos sent to France, several points are in dispute. Was there a deliberate plot to send them so that they might be shot? If so, who was in the conspiracy? Were the cos in real danger? And how important was the interference of the NCF?

I have no quarrel with Kennedy for dismissing the narrowly-based and 
biased account of Graham out of hand, nor for sending Boulton's purely derivative account packing after it. But in view of Kennedy's careful study of so many sources, it is surprising to find him uncritically accepting John Rae's evaluation of the episode (Conscience and Politics, 1970). Indeed, Rae's treatment of this subject has always seemed to me to be a flaw in an otherwise good and judicial book; in his anxiety to prove that the whole incident has little significance, and certainly no sinister import, he departs from his usual careful analysis. Since this is not a review of Rae's book, I will not go into details except to say that Rae makes use of a piece of demonstrably unreliable evidence, contradicts himself more than once within a few pages, confuses the nature and date of promulgation of two important administrative changes, and is (this last excusably) ignorant of certain pieces of evidence now available.

All of this suffices only to cast some doubts on Rae's and Kennedy's conclusion that there was no high-level Army or War Office plan to shoot a few cos; it does not amount to proof that there was such a plot. I have to be content to leave it at that, although I think there is other suggestive evidence, which I may put together at some other time. I am also inclined to believe that NCF intervention and continued monitoring played a valuable, possibly a crucial rolc in the sequence of events. The painful anxiety of the Prime Minister, Asquith, and his evident sense that he could better rely on the integrity and information of the NCF than he could on that of his War Office officials is in itself telling evidence.

The story of the NCF and the cos sent to France is of importance not only as a good historical whodunit but for its bearing on the whole question of the motivation and methods of the Fellowship's leaders. One of the controversial issues within the NCF was that of the nature and extent of legitimate political action. The young Quaker leaders came to hold that the Fellowship should refrain from direct approaches to government officials and should not campaign for release of the absolutists or for betterment of conditions. Kennedy understands well the importance to many of the prisoners themselves of knowing that they were not forgotten by their friends outside, and is critical (rightly, in my view) of the FSC for trying to impose a particular and sophisticated pacifist viewpoint on those to whom it made no sense, and many of whom were not themselves Quakers. However, there are ways in which the importance of the controversy goes far beyond this. Politically, the extraordinary amount of time taken up in Parliament throughout the war by the affairs of the small band of cos reflects the persistence of a liberal nerve in the body of that institution which could easily be touched by cases of seeming injustice, not the less because the Government was still nominally under Liberal leadership.
More profoundly still, it is arguable that the NCF-for all the pettiness and sometimes arrogance of some of its members-did have a function to perform as the conscience of the nation. When Grubb spoke up to question the direction the young Friends were taking, he was not speaking just out of compassion for those in jail (important as this was); he was demanding that Friends preserve their humanness and their divinity by practising humanity. Further, he stressed that it was not foreign to the Quaker tradition to approach Governments for relief from injustice: this was not "whining", but an appeal to the better side of those in positions of power. Grubb may well have had in mind that George Fox himself had directly addressed both Cromwell and Charles II, treating them as men like all others, capable of acting justly or unjustly, and deserving to be given the choice.

Along similar lines, but without the rhetoric of religion, Russell also stressed the need to deal with officials as people, and dwelt on what he saw as a grave moral danger to his country (no one questions the sincerity of Russell's love for England) in allowing war and militarism so to corrupt the country's institutions and its leaders that civil liberties disappeared and brutalities became acceptable.

Any one who writes about the NCF is bound to try to assess its effectiveness. In terms of goals, Kennedy reaches the acceptable conclusion that the NCF did not do well in terms of its major stated aims, but that it worked well in relation to intermediate objectives which presented themselves along the way. The pitfall here is surely that we are inclined to measure importance too narrowly by measurable success. If the First World War pacifists were right they were not less so because they were not successful. Even the smallness of their numbers is hardly a good stick to beat them with-perhaps it should be laid on the backs of those who did not resist war and conscription. To paraphrase a text much in Russell's mind at this time, perhaps we should question the actions of those who did "follow a multitude to do evil", not those who tried feebly to stem the tide.

The new University of Arkansas Press is to be congratulated on an attractive production; this is not the place to detail the several points at which minor errors could have been avoided by more rigorous editing. A final word of praise goes to Kennedy's most useful annotated bibliography.

Kingston, Ont. 